\title{
Development of Risk Management System in Private School General Education
}

\author{
Pantep Pattanajureepan ${ }^{1}$, Chaiyuth Sirisuthi ${ }^{1} \&$ Subunn Ieamvijarn ${ }^{2}$ \\ ${ }^{1}$ Faculty of Education, Mahasarakham University, Mahasarakham Province, Thailand \\ ${ }^{2}$ Faculty of Mahasarakham Business School, Mahasarakham University, Thailand \\ Correspondence: Pantep Pattanajureepan, Faculty of Education, Mahasarakham University, Mahasarakham \\ Province 44000, Thailand. E-mail: punteap@hotmail.com
}

\author{
Received: September 29, 2013 Accepted: October 15, 2013 Online Published: December 31, 2013 \\ doi:10.5539/ass.v10n1p276 \\ URL: http://dx.doi.org/10.5539/ass.v10n1p276
}

\begin{abstract}
The study aimed to; study current situations and problem, develop the appropriated system, and evaluate the outputs of risk management in/for private school, general education, Thailand. The research designed into three phases based on the objectives of the study and research and development (R\&D) was employed. The questionnaires, semi-structured interview forms, and evaluation forms were used as research tools and percentage, means, and standard deviation (SD) were selected for statistical analysis tools. Moreover, Multi-Attribute Consensus Reading (MACR) was employed for pre-system implementation. The research finding showed that - the current situations and problems in risk management in private school today Thailand viewed by four aspects included strategic, operational, financial, and compliance. In the risk management processes divided into five steps consisted of determining the objectives, investigation, assessment, administration, and monitoring and evaluation. The appropriated risk management system was developed with five major factors and 22 sub-factors for inputs. The feedbacks of the developed risk management system implementation showed that the private school administrators and teachers comprehensive aware of risk management in high level. The developed system help to decrease and be able to manage the risks. This results of implementation of the developed risk management system was satisfied by school administration and teachers in high satisfaction.
\end{abstract}

Keywords: system development, risk management, private school, general education, Thailand

\section{Introduction}

Thailand National Development Plan (2012-16), issue 11, mentioned about the risks caused by global, regional, and national changes. Collaboration commitment framework was adopted for ASEAN integration by 2015 (The Office of National Economic and Social Development Commission, 2011). Risks could occurred in any levels, sizes and fields of organizations and institutions and it was divided external and internal. In the field of education, Thailand considered risks as a significant obstacle for accomplishing the goal and objectives of the educational organization. Responding to this, Thailand Ministry of Education proposed to the educational institutions both public and private to be aware of the risks occurring during daily work operation. The organization goal and objectives should be precise, specific, and accessible (the Office of Permanent Secretary Ministry of Education, Thailand, 2007).

The private schools in Thailand are operating under the Private Schools Acts under the Office of Private Education Commission, Thailand's Ministry of Education. The educational standard are applied equally among public and private educational institutions (the Office of Promotion for Private Education Commission, 2008).

In Thailand, there were two ways of government support for private schools from Basis Education department, Ministry of Education included demand-side financing and supply-side financing. In one hand, the demand-side financing the supports was based on 15 years free of charge policy included books, learning equipment, uniform, and learning activities for the students. On the other hand, the supply-side financing is directly granted to the student enrollment and teachers basic supports. However, the government financing was 70 percent compared to public school. For the current problems for private schools in term of teachers and staffs - there are absent of encouragement and motivation for whom teaching in the private school. Unlike the public school's teacher and 
staffs, there were no salary support, no opportunity to improve academic position, no position revenue, no living expenditure and support, no medical welfare, and so on for the private school teachers and staffs. As a result of the above problems happened in private schools, the teacher trend and movement for applying to work in public schools caused the inadequate of teachers in private school. In addition, the Office of Promotion in Private Education Commission was allocated only 10 percent from the government for dealing with private schools (Wanicha, 2009). By contrast the research study conducted by the Office of Private Education Commission founded that the private sector could decrease the national expends ten times compared to public schools in providing educational services in Thailand (Jamrad, 1995).

The Thailand constitutions and government policies also considered as big challenges for private school in Thailand. In the educational law, article 43 determined that the educational service must providing free within 12 years (from grade 1-12), that caused private schools could compete with the public schools in term of number of the students. At the same time, the Ministry of Education under the supervision of the government sets up the various new policies and mechanism for education and specific only for public schools for the implementation. The unbalancing treatment of the government between private and public school caused high risk in operating the private schools in Thailand. As a result, the number of student enrolled in the private schools are frequently decreased while the government introduced new model for public schools included bilingual teaching and learning model, pilot schools, Buddhism schools, and also many vocational programs. Therefore, as the nature of doing business the decreasing number of the students is a big challenge for private investment (Apisit, 2008).

The Risk Management in private schools was considered as a significant task in order to alleviate the problems both internal and external as well as how to deal with them. The level of risks that can be acceptable were if we can assess, control, and investigate systematically. The following up of the accomplishing the goals and objectives by looking at the major responsibilities and annual action plan complementation will be considered. Even though, risk management which is the significant challenge for private schools not occurred as systematic management yet. Therefore this research will be focused on the development of risk management system for private schools, general education in Thailand.

\section{Research Objectives}

The study aimed to; study current situations and problem, develop the appropriated system, and evaluate the outputs of risk management in/for private school, general education, Thailand.

\section{Research Methodology}

Research and Development (R\&D) was employed as nature of this research. The questionnaires, semi-structured interview forms, and evaluation forms were used as research tools and percentage, means, and standard deviation (SD) were selected for statistical analysis tools. Moreover, Multi-Attribute Consensus Reading (MACR) was employed for pre-system implementation. There were three fieldworks selected for focus group discussion comprised of; Mukdahan, Mahasarakham, Nakornrachsima Provinces, Thailand. This research study was designed into three phases comprised of current situation and problems investigation, system development and verification, and system implementation and evaluation.

\begin{tabular}{|c|c|c|}
\hline $\begin{array}{l}\text { Phase 1: Current Situations } \\
\text { and Problem Investigation } \\
\text { 1. Reviewing ideas, concepts, } \\
\text { theories, and principles of the } \\
\text { system } \\
\text { 2. Focus group discussion for } \\
\text { situation analysis and problems } \\
\text { investigation } \\
\text { 3. Synthesis and analysis the } \\
\text { data both secondary and } \\
\text { primary to figure out the inputs }\end{array}$ & $\begin{array}{l}\begin{array}{l}\text { Phase 2: } \\
\text { Development } \\
\text { Verification }\end{array} \\
\text { 1. Studying the best practices } \\
\text { and } \\
\text { where successful in risks } \\
\text { management } \\
\text { 2. System drafting } \\
\text { 3. Expert approval } \\
\text { 4. Pre-system implementation } \\
\text { (MACR technique is } \\
\text { employed) } \\
\text { 5. System verification }\end{array}$ & 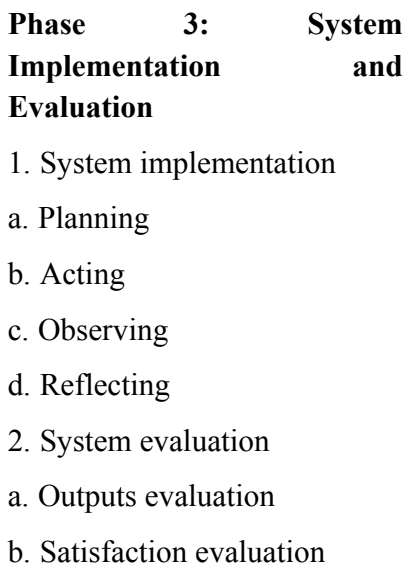 \\
\hline
\end{tabular}

Figure 1. The research process for risks management system development in private school, Thailand 
Phase 1: This step focused on the risks management situations in private school, general education, Thailand. The documents, approaches, theories, ideas, and principles regarding to risk managements, system, and private school were reviewed. There were 36 private schools administrators purposive selected for focus group discussion.

Phase 2: Developing the appropriate risk management system based on the both secondary and primary data that from the reviewing literature and best practice data collection. The tentative system is developed in this phase with expert's approval and verification.

Phase 3: the evaluation process of the developed risks management system implementation in the private school. The developed risks management system was implemented in Nokorachsima Province, Thailand. The implementation period was six months with PAOR techniques (Planning, Acting, Observing, and Reflecting).

\section{Findings}

The findings were presented into three main parts;

\subsection{The Current Situations and Problems of Risk Management in Private Schools}

The major problems and factors in the risks management in private school reflected in four main fields included strategic, working operation, financial implementation, and compliance enforcement.

- Risk in the strategic: the academic planning in the private schools showed unclear and complicated way which caused administers and teacher unclear what they were doing. The curriculum development was not appropriated and responds to the social change and needs of the current situations in the society. The teaching and learning process was difficult to understand especially for the students. Moreover, the overall strategic plan and strategic implementation was need really respond to the students needed and go against the theory of student-centered. The teachers were teaching overloaded that caused the teaching quality improvement. The strategic plan implementation assessment was absents mostly in the private schools.

- Working operation risks: in this part was mentioned mostly on the teachers teaching and working in the private schools. Most of the private schools were facing of the adequate of teachers. Based on this reason the private schools decided to recruit the unqualified or no experiences teachers to teach. At the same time the private schools are lacks of motivation systems for teachers. It seemed private schools in Thailand played a role as internship for the state schools. Being the state or government served-teacher was a dream for those who want to be a teacher in Thailand. The welfare provided by the government schools were also pull factor of the teachers from the private schools.

- Financial risks: the lack of government financial supports for private schools caused the financial management under the insufficiency and out of the plan. The more insufficiency finance and budget appeared in the private higher schools where it was required learning equipment and experiment tools.

- The compliance risks: The regulations and laws regarding to the education were not update while the current world change is dynamic. Moreover the changing government in Thailand also considered as an obstacle for the private schools to grow because the new comer government comes up with the new policy including education policy. The pro-poor government in Thailand either set up many regulations for private sectors including private schools. Because of that the private schools could not be able to develop themselves in the full capacity and potential. By concluded the private schools current situations based on the data gathered from the focused group discussion among 36 private school administrators showed in the low performance and under the attached by the external and internal risks caused the change in national, regional, and global level. Based on the findings the fours factors required a proper risk management system to deal with. 
Table 1. The current situations and problems of risk management in private schools (Pre-test)

\begin{tabular}{clccc}
\hline No. & \multicolumn{1}{c}{ Dimensions } & Mean & S.D & Degree \\
\hline $\mathbf{1}$ & Staffs communication in risk management & 2.16 & 0.39 & Low \\
$\mathbf{2}$ & Responding to strategic plan and annual plan & 2.33 & 0.62 & Low \\
$\mathbf{3}$ & Risks management committees & 2.12 & 0.51 & Low \\
$\mathbf{4}$ & SWOT analysis of private schools & 2.41 & 0.62 & Low \\
$\mathbf{5}$ & Risks factors investigation & 2.16 & 0.47 & Low \\
$\mathbf{6}$ & Risks factors and management reports & 2.22 & 0.24 & Low \\
$\mathbf{7}$ & Risks management analysis & 2.25 & 0.45 & Low \\
$\mathbf{8}$ & Risks indicators formulation & 2.15 & 0.47 & Low \\
$\mathbf{9}$ & Evaluation process of risks & 2.12 & 0.49 & Low \\
& The average of dimension & 2.17 & 0.47 & Low \\
\hline
\end{tabular}

\subsection{Developing the Risks Management System for Private School General Education}

The risks management system was developed based the data gathered from the best-practices of three private schools where more or less considered as successful schools in risks management. Focused group discussion among 36 private schools administrators was conducted. Three major groups of educational experts were selected for Multi-Attribute Consensus Reading (MACR) seminars. The best practices of each case explained by four main parts as in the following;

\section{Inputs Factors:}

- Risks in strategic plans: this plans are included academic plans and activities, curriculum development and administration, curriculum verification and assessment, teaching and learning process, promoting research activities, credits transfer follow up system, working standard formulation, situations, problems, and need analysis mechanisms, training and capacity building, quality assurance development, and so on. The results showed that each case has alternative and differences techniques in risks management depend up on their current contexts. But each case were aware of developing the strategic plans in order to respond to any risks happening in the schools.

- $\quad$ Risks in work operations: the human resources management was considered as very important part for work operation. The balancing between working loads, staffs, teachers, and students was a requirement in private schools. The qualifications and criteria of staffs including teachers were considered as a key point in moving forward the work operations. At the same time, some mechanisms also developed for staffing such as work assessment, qualification and performance assessment, professional development, research activities promotion among staffs and teachers, and professional administrators for management teams. Among each case, thee private schools are operated frequently.

- Risks in Financial Administration: the financial plans played a very import role in financial management. The auditing mechanism has to be strict and transparency. Moreover, the physical resources in the private schools have to be manage and available for teaching and learning process.

- Risks in compliance: the changing and verification of government's policy, regulations and including laws caused the private schools management system changes. The study of those compliances changes was a critical task for the management teams to respond. The proper respond and applying law enforcement were the maintained the risk happening in the compliance part.

- Risks in Security: this security part were included the security of the building, the environments of the schools both in-out classroom, foods and waters, student personal property, electricity, and overall security for teachers and students in private schools.

By concluded, the above best practices were employed as the inputs factors for risks management system development (see figure 2). 


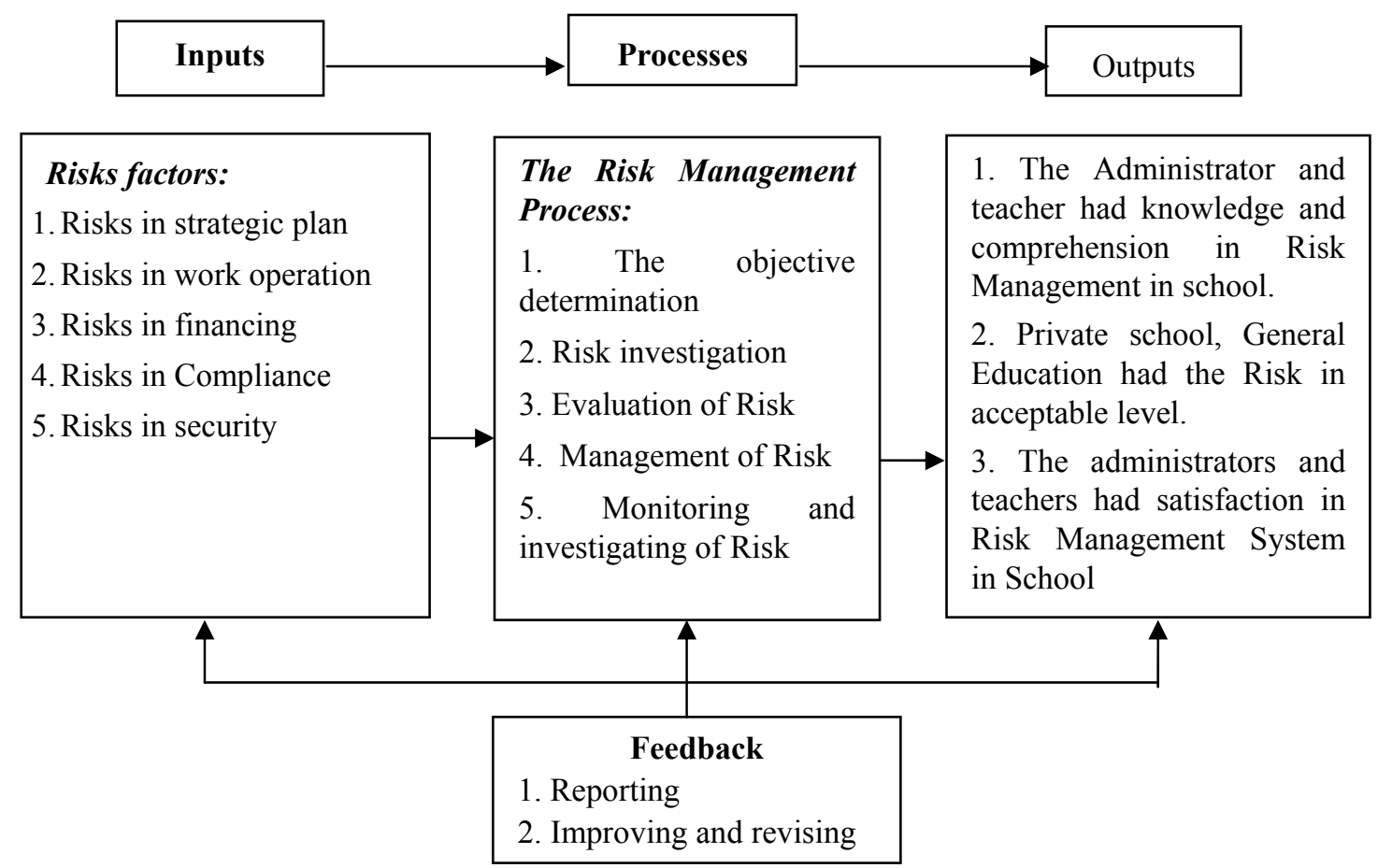

Figure 2. Risks management system

\subsection{Developed Risks Management System Implementation}

Two private schools were selected to implement the risks management system. The criteria of the school; the private school with general education offered teaching and learning from kindergarten to upper secondary level, the private schools where its administration autonomy, willing to try a new developed system, and low performance in risks management system. The risks management system guideline book was used for selected private schools.

The results of implementation showed that; the comparative average scores of the knowledge and awareness of selected private schools administrator between pre-test and post-test - the administrators are more aware and understand in the "High" level. The system implementation were based on five factors included; the strategic, operational, financial, and the compliance which refers to the rule, regulation, and law enforcement. The implementation process were follow the five steps included; determining the objective, risks investigation, risks assessment, risks management, and risks monitoring and evaluation. After six months implementation process the risks happening in the selected private schools were decreased significantly. Overall, the administrators and teachers in the selected private schools satisfied with the developed risks management system introduced by the researchers. Statistically, the administrators and teacher's satisfaction showed "highest satisfaction".

\subsection{Evaluation Results}

The overall situation and feedback of the risks management system implementation results showed that teachers who were participated in the applying of risks management satisfied in the high level. 
Table 2. The current situations and problems of risk management in private schools (Post-test)

\begin{tabular}{clccc}
\hline No. & \multicolumn{1}{c}{ Dimensions } & Mean & S.D & Degree \\
\hline $\mathbf{1}$ & Staffs communication in risk management & 4.66 & 0.49 & Very high \\
$\mathbf{2}$ & Responding to strategic plan and annual plan & 4.58 & 0.51 & Very high \\
$\mathbf{3}$ & Risks management committees & 4.75 & 0.45 & High \\
$\mathbf{4}$ & SWOT analysis of private schools & 4.17 & 0.38 & High \\
$\mathbf{5}$ & Risks factors investigation & 4.41 & 0.51 & High \\
$\mathbf{6}$ & Risks factors and management reports & 4.16 & 0.83 & Very high \\
$\mathbf{7}$ & Risks management analysis & 4.58 & 0.51 & Low \\
$\mathbf{8}$ & Risks indicators formulation & 2.33 & 0.45 & High \\
$\mathbf{9}$ & Evaluation process of risks & 4.25 & 0.45 & High \\
& The average of dimension & $\mathbf{4 . 2 1}$ & $\mathbf{0 . 5 2}$ & High \\
\hline
\end{tabular}

\section{Conclusions}

The findings of this study obtained the Risk Management System in Private School, General Education which was appropriate with current situation, practical, and useful for school work management to accomplish goal based on major responsibility of school

\section{Recommendations}

\subsection{For the Administrators and Teachers}

1). Private school's owners, principals, administrators, and teachers should be aware the risks managements and capable to manage and decrease the risks occurred in management process, especially in the world of competition and change.

2). Problems and needs assessment should be conducted before risk management system application.

3). Educational Quality developers should include the risk management in the process of quality assurance indicators and tools.

\subsection{For Researchers}

1). Collaborative research on risks management/system should be conducted in order to respond properly to the new risks.

2). Researchers in the fields of educational managements should be more considered on the risk management topic in the various levels and fields.

\section{References}

AIRMIC, ALARM, IRM. (2002). A Risk Management Standard. The Institute of Risk Management.

Akarapatompong, P., \& Amonpechkool, T. (2003). Development of Risk Management in Supply Division, the Office of Plan and Financial management. Chulalongkorn University, Thailand.

Chantawee, P. (2010). Development of Assessment and Controlling System of Educational Risk for School: An Assessment as Empowerment. Doctor of Philosophy Thesis. Mahasarakam University, Thailand

Chuaytrakool, D. (2008). Risk Management in Basic Education School. Doctoral Dissertation. Bangkok: Silpakorn University, Thailand.

Committee of Sponsoring Organization of the Tread Way Commission. (2004). Enterprise Risks Management Framework. Retrieved from http://www.erm.coso.org

Gray, C. F., \& Larson, E. W. (2006). Project management - the managerial process. Boston, Mass: Irwin /McGraw-Hill.

Krisjaroen, A. (2008). Development of Management Model in Catholic Private School under the Monk in next Decade. Doctor of Education Thesis in Educational Administration, Faculty of Education, Burapa University.

Lunt et al. (2009). Approaches to Risk and Consumer Policy in Financial Service Regulation in the UK. 
Retrieved from http://www.qualitative-research.net/index.php/fqs/article/view/60/124

Mahasarakam University. (2012). Handbook for Risk Management and Internal Control. 2012-13 Budget Plan, Thailand.

Massingham, P. (2010). Knowledge risk management: A framework. Journal of Knowledge Management. http://dx.doi.org/10.1108/13673271011050166

Nongmak, J. (2001). The Practice of Educational Quality Assurance. Bangkok: Sun Printing. Thailand

Pataramontree, U. (2002). Internal Audit and Control: Approach and Case Study. Master of Business Administration Thesis. Bangkok: Thammasat University, Thailand.

Pataraprasit, W. (2009). Development of Model for Supporting the Private School in Basic Education. Doctor of Education Thesis, Chulalongkorn University, Thailand.

Property Marketing of Thailand. (2003). Guidelines for Risk Management. Bangkok: Price Water House Coopers.

Risk Management Commission, Institute of Science and Technology Research of Thailand. (2009). Handbook of Risk Management. Retrieved from http://www.tistr.or.th/tistr2006/code/tistrorg/report/file/risk20051012.pdf

Rodrigues, A. G. (2001). Managing and Modeling Project Risk Dynamics: System Dynamics Based Framework. The Fourth Europe Project Management Conference. p. 58.

Ru-pan, P. (2003). Development of Assessment System in Work Practice of Basic Education Commission. Doctor of Education Thesis. Bangkok: Chulalongkorn University, Thailand.

Soontarayoot, T. (2007). Educational Risk Management. Bangkok: Netikool Printing Ltd.

The Office of Ministry of Interior. (2007). Handbook of Risk Management. The Office of Ministry of Interior. Bangkok, Thailand.

The Office of Permanent Secretary. (2009). Risk Management of the Office of Permanent Secretary. Retrieved from http://www.nidtep.go.th/nidtep/articles/trainer6.doc

The Office of Promotion for Private Education Commission. (2009). Private School Act 2007. Bangkok: PPEC Printing.

Udontani Rajabhat University. (2010). Handbook of Risk Management for Udontani Rajabhat University. Thailand.

University of Western Sydney. (2008). Hazard Identification, Risk Assessment and Control Procedure. Australia

Wilson. J. (1999). Risk reviews and using risk management strategy. In Clinical risk modification: A route to clinic governance. Oxford: Butterworth-Heinemann.

\section{Copyrights}

Copyright for this article is retained by the author(s), with first publication rights granted to the journal.

This is an open-access article distributed under the terms and conditions of the Creative Commons Attribution license (http://creativecommons.org/licenses/by/3.0/). 